\title{
Free Trade Agreements With The United States: 8 Lessons For Prospective Parties From Australia's EXPERIENCE
}

\author{
Stephen R. Tully* \\ University of Sydney, University of New South Wales, Australia
}

\begin{abstract}
This article identifies 8 key lessons for those States contemplating a free trade agreement with the United States (U.S.) arising from Australia's experience. The standards of intellectual property protection under the Australia-U.S. Free Trade Agreement and their impact on pharmaceutical prices in Australia are a particular focus. Prospective parties must first conduct a national interest self-assessment which reviews the desired strength of intellectual property protection under national law and their preference for using flexibilities available to them under the existing international intellectual property rights framework. The United States negotiates free trade agreements in light of previous ones, negotiating outcomes obtained in other fora and the decisions of international trade tribunals. Negotiations typically occur behind closed doors, which is a process having adverse implications for transparent decision-making, public consultation periods and contributions from interested non-governmental actors. A concluded agreement will build on prior treaties and influence the course of future international arrangements. But the impact of a United States free trade agreement is not always clear, including because of a lack of reliable data, and the extent of national legal change is a contested issue given existing reform agendas and external influences. The United States seek to redesign national health care systems in its own image and had little success in Australia's case. National legal systems need not be harmonised: although there can be some convergence in intellectual property rights regimes, significant differences may also remain. Negotiators must reconcile competing cultures, philosophies and perspectives between States for a free trade agreement to be worthwhile.
\end{abstract}

\section{CONTENTS}

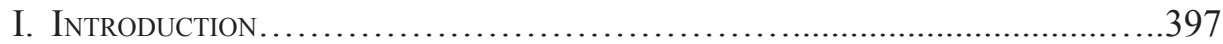

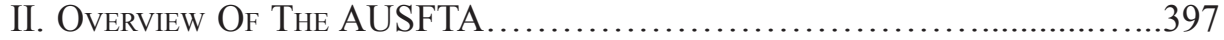

III. Eight Lessons From The Negotiation Of The AUSFTA........................398

A. States must assess National Interests before adhering to a Free Trade

Agreement. .398

\footnotetext{
* Barrister, St James' Hall Chambers, 6/169 Phillip Street Sydney NSW 2000; Tutor, Law Faculty, University of Sydney; Part-time Lecturer, Law Faculty, University of New South Wales; He can be reached at stully@stjames.net.au.
} 
B. Free Trade Agreements build on U.S. Past Experience.................401

C. Free Trade Agreements are typically negotiated in secret.......... 404

D. The Intellectual Property Provisions of a Free Trade Agreement can influence National Health Care Systems.........................406

E. The Impacts of a U.S. Free Trade Agreement may not be clear...409

F. A U.S. Free Trade Agreement does not necessarily lead to a Harmonisation of or Convergence between National Legal Systems 412

G. A Free Trade Agreement can influence Future International

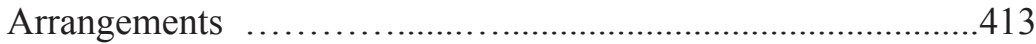

H. A Free Trade Agreement must reconcile Competing Cultures and

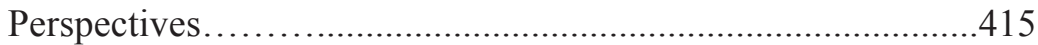

IV. Conclusions......................................................4 418 


\section{INTRODUCTION}

The free trade agreement concluded between Australia and the United States (U.S.) was one of the first bilateral agreements between the United States and a developed country. The Australia-U.S. Free Trade Agreement (AUSFTA), ${ }^{1}$ numbering some 1000 pages, covers a multiplicity of topics. Part II provides a very brief overview. This article then reviews the literature and other material relevant to the standards of intellectual property protection provided under this agreement. Because AUSFTA's implications for Australia's healthcare system and pharmaceutical prices were matters of considerable controversy when the treaty was first concluded in 2004, this article will focus on developments since that time with particular reference to one of the critical drivers: pharmaceutical industry interests. The key lessons for other States as derived from Australia's particular experience are identified and discussed in Part III. Part IV briefly puts several conclusions.

\section{Overview OF THE AUSFTA}

The AUSFTA was promptly negotiated and finalised. Negotiations commenced in November 2002. Trade representatives met over five rounds of negotiations between March 2003 and February 2004. The agreed text was finalised on February 8, 2004, signed on May 18, 2004, publicly released on 4 March 2004 and tabled in Parliament on March 8, 2004. The AUSFTA was then referred for parliamentary scrutiny, with two committees endorsing the agreement. ${ }^{2}$ These committees confronted a very tight deadline in which to publicly consult and consider submissions about a complex agreement covering a wide array of controversial issues.

The U.S. Free Trade Agreement Implementation Act 2004 (Cth) was passed in August 2004 to implement the AUSFTA. ${ }^{3}$ This legislation did not:

represent the wholesale adoption of the US intellectual property regime. We have not stepped back from best practice elements of Australia's copyright regime-but we have strengthened protection in certain circumstances-providing a platform for Australia to attract and incubate greater creativity and innovation. ${ }^{4}$

\footnotetext{
United States-Australia Free Trade Agreement (May 18, 2004) T.I.A.S. No. 6422; [2005] A.T.S. 1.

2 Parliament of Australia Senate Select Committee on the Free Trade Agreement between Australia and the United States of America, Final Report on the Free Trade Agreement between Australia and the United States of America (2004); Joint Standing Committee on Treaties, The Australia-United States Free Trade Agreement, Report No. 61 (2004). The Copyright Legislation Amendment Bill 2004 was referred for review to the Senate Legal and Constitutional Legislation Committee on 6 December and that Committee was required to provide its report on the very next day.

3 Treaties are not "self-executing" under Australian law but first require implementing legislation to take effect. For a review of the legislative provisions, see Australian Parliamentary Library, Free Trade Agreement Bill 2004 (Сth), Parliamentary Bills Digest No. 21 (2004-2005).

4 Hon. Mark Vaile, Minister for Trade, Reading Speech introducing the U.S. Free Trade Agreement Implementation Bill 2004, House of Representatives Hansard (Jun. 23, 2004), 31218.
} 
The principal political opposition party supported the legislation but identified several problems arising from enhanced copyright protection. ${ }^{5}$ The minor parties opposed the AUSFTA, with one commenting that:

By adopting the worst aspects of American law, we are undermining the creative potential of many industries and the creative enjoyment and participation of our citizens. ${ }^{6}$

Additional legislation clarifying several copyright changes followed. These produced "some important, and in some cases radical" amendments to copyright protection in Australia whose effect and interaction with the existing law was "complex and unpredictable." The scheme commenced on January $1^{\text {st }} 2005$. Australian copyright law thus underwent three separate tranches of amendments to ensure compliance with AUSFTA, with the final implementation stage completed in December 2006.

Intellectual property is addressed in Chapter 17 of the AUSFTA and by accompanying side letters. ${ }^{8}$ Chapter 17 covers trade marks (Article 17.2), domain names (Article 17.3), copyright (Article 17.4), designs (Article 17.8), patents (Article 17.9), pharmaceutical and other data (Article 17.10), encrypted programcarrying satellite signals (Article 17.7) and enforcement (Article 17.11). The Chapter also outlines the liability of internet service providers (Article 17.11.29), the consequences for circumventing technological measures which control access (Article 17.4.8) and provisions for those who knowingly remove or alter electronic rights management information (Article 17.4.9).

\section{Eight Lessons from the Negotiation of the AUSFTA}

\section{A. States Must Assess National Interests Before AdHERING TO A FREE TRADE AGREEMENT}

Free trade agreements are concluded by States in their sovereign capacity consistent with their perceived national interest. The negotiating objectives of the United States included establishing standards which built on existing international intellectual

5 Colette Ormonde, Copyright Overboard? The Debate After the Australia-United States Free Trade Agreement, InCITE 8 (2004).

6 Cth, In Committee, Senate, 12 Aug. 2004, 264051 (Senator Kerry Nettle) (Austl).

7 Jacob Varghese, Guide to Copyright and Patent Law Changes in the US Free Trade Agreement Implementation Bill 20048 (Australian Parliamentary Library Current Issues Brief No. 3, Aug. 3, 2004).

8 For an overview of Chapter 7, see Christopher Arup, The United States-Australia Free Trade Agreement - The Intellectual Property Chapter, 15 A.I.P.J. 205 (2004); David Richardson, Intellectual Property Rights and the Australia-United States Free Trade Agreement (Australian Parliamentary Library Research Paper No. 14, 2003-4). See generally Department of Foreign Affairs and Trade, Australia-United States Free Trade Agreement - Guide to the Agreement (2005); Vasantha Stesin \& Paul Power, Patents and the Australia-U.S.A. Free Trade Agreement, 14 H.L.B. 1 (2005). 
property agreements; enhancing protection for new technical areas (such as internet service provider liability); making Australia apply legal protection more consistent with U.S. law and practice; and strengthening domestic enforcement procedures (including criminal penalties) to address piracy and counterfeiting. ${ }^{9}$

Australia's negotiating objectives were to implement internationally-agreed intellectual property standards and maintain a balance between intellectual property rights holders and the interests of others (including users, consumers, communication carriers and distributors, as well as the education and research sectors). ${ }^{10}$

Australia agreed to the AUSFTA not because the copyright provisions were considered desirable or because Australia is a major producer of generic pharmaceuticals. There is at most a small industrial constituency in Australia resisting U.S. demands for market access. The potential for higher pharmaceutical prices was tolerated because Australian agricultural and farming interests would benefit. ${ }^{11}$ Australia also perceived advantages for government procurement. In addition to the incumbent government's interest in establishing closer economic and political ties with the U.S., Australia's motivation included furthering Asian trade, remedying stalled multilateral trade negotiations, removing U.S. tariffs against the Australian wine industry and lamb imports, and securing access to senior Bush administration officials.

Australia's acquiescence to U.S. demands to expand intellectual property rights protection was consistent with its preconceived policy to that end. ${ }^{12}$ Australia sought to increase U.S. market access, facilitate North American foreign investment and enhance protection for its American investments. Australia has a relatively small intellectual property rights-oriented industry so sacrificed very little to achieve these objectives. Strengthening intellectual property rights was unlikely to adversely affect Australia's economy. Australian negotiators sought to promote Australia's trade liberalization policies and provide economic opportunities for Australian businesses. Thus the Australian Minister for Trade said:

We are pursuing the concept of a Free Trade Agreement with the United States because we see an opportunity to open better opportunities for Australian exporters in the world's largest and most dynamic economy. ${ }^{13}$

$9 \quad$ United States Trade Representative Robert Zoellick, Letter to Congress (2002), available at www.ustr.gov/releases/2002/11/2002-11-3-australia-byrd (on file with the author).

10 Dep't Foreign Affairs \& Trade, Statement of Australia Objectives, available at www. dfat.gov.au/trade/negotiations/us_australia_objectives.html (on file with the author).

11 Frederick Abbott, Intellectual Property Rights in Global Trade Framework: IP Trends in Developing Countries, 98 Am. Soc'y. InT'L L. Proc. 95, 97, 99 (2004). See also Kayleen Manwaring, The Price of Beef in a Copyright Market: the Effects of Chapter 17 of the Australia-US Free Trade Agreement, 23 COPY RePTR 60 (2005).

12 Ralph Fischer, The Expansion of Intellectual Property Rights by International Agreement: A Case Study comparing Chile and Australia's Bilateral FTA Negotiations with the US, 28 Loy. L.A. Int'L \& Comp. L. Rev. 129, 164 (2006).

13 Hon. Mark Vaile, Australian Minister for Trade, Australia and Trade: Our Nation's Strength, Our Nation's Future, Speech delivered at the launch of the Trade Outcomes and Objectives Statement, Canberra (Apr. 3, 2001). 
Nevertheless, the value to Australia of concluding a free trade agreement with the U.S. attracted controversy. ${ }^{14}$ Tightening intellectual property rights protection to increase the level of rent for private industry could inflict substantial harm to a State. Existing intellectual property rights should not be enhanced absent a clear justification and after a State has comprehensively analysed the economic and social costs and benefits.

Thus, States such as New Zealand for example should be cautious about blindly following Australia and accepting the standard terms of a U.S. free trade agreement. ${ }^{15}$ The United States seeks significantly higher levels of intellectual property protection than currently provided under New Zealand law. The AUSFTA increased intellectual property protection in Australia without a full public debate or clearly-drawn justifications. Intellectual property protection was traded off against concessions obtained in other areas. But New Zealand is in a weak negotiating position relative to the United States: it would pursue greater access to the U.S. agricultural market but has little to offer the United States other than strategic gains (for example, limiting polarisation within the Asia-Pacific region). Although some changes required by a New Zealand-U.S. Free Trade Agreement would be beneficial, significant economic cost would also be imposed on New Zealand users, the economy, and New Zealand's creative industries.

Furthermore, the AUSFTA has implications for a single agency with which to regulate pharmaceutical products within a trans-Tasman market. The Australia New Zealand Therapeutic Products Authority (ANZTPA) was intended to replace both the Australian Therapeutic Goods Administration (TGA) and the New Zealand Medicines and Medical Devices Safety Authority. ${ }^{16}$ The ANZTPA could inherit significant obligations which were imposed on the TGA by the AUSFTA which could significantly impact pharmaceutical regulation in New Zealand. ${ }^{17}$ Thus prospective parties such as New Zealand which contemplate a free trade agreement must first assess the compatibility of their ideology, national interests and perspectives with that of the United States.

14 Compare Peter Drahos and David Henry, The Free Trade Agreement Between Australia and the United States Undermines Australian Public Health and Protects US Interests in Pharmaceuticals, 328 Brit. Med. J. 1271 (2004); Andrew Stoler, Australia-U.S. Free Trade: Benefits and Costs of an Agreement, in Free Trade Agreements: U.S. Strategies AND Priorities 95 (Jeffrey Schott ed., Peterson Institute for International Economics 2004).

15 Anna Kingsbury, Intellectual Property Provisions in Bilateral and Regional Free Trade Agreements: What Should New Zealand Expect from a New Zealand/United States Free Trade Agreement?, 10 N.Z.B.L.Q. 222, 234-35 (2004).

16 See further Australia-New Zealand Agreement for the Establishment of a Joint Scheme for the Regulation of Therapeutic Products (Dec. 10, 2003) [2003] ATNIF 22; JoINT Standing Committee on Treaties, Parliament of Australia, Inquiry into the Agreement Between the Government of Australia and the Government of New Zealand for the Establishment of a Joint Scheme for the Regulation of Therapeutic Products, Report No. 62, Canberra (2004).

17 Thomas Faunce, Kellie Johnston \&Hilary Bambrick, The Trans-Tasman Therapeutic Products Authority: Potential AUSFTA Impacts on Safety and Cost-Effectiveness Regulation for Medicines and Medical Devices in New Zealand, 37 Vict. U. Wellington L. REv. 365 (2006). 


\section{B. Free Trade Agreements Build on U.S. Past Experience}

The AUSFTA established an agreed floor: the United States and Australia will provide a minimum level of protection and any additional protection or enforcement if not inconsistent with that treaty. Australia and the U.S. have moreover affirmed the importance of existing international frameworks for intellectual property protection. In particular, the AUSFTA will be interpreted in light of the principles and rules established by the Agreement on Trade-Related Aspects of Intellectual Property Rights (TRIPS).$^{18}$ Thus Australia and the United States "affirm their rights and obligations with respect to each other under the TRIPS Agreement" (Article 17.1, AUSFTA). They also "affirm their existing rights and obligations with respect to each other under existing bilateral and multilateral agreements to which both Parties are party, including the WTO [World Trade Organization] Agreement" (Article 1.1, AUSFTA).

TRIPS contains provisions ("flexibilities") which seek to ensure that public health needs are met by lowering costs, increasing access to medicines and facilitating generic imports. ${ }^{19}$ These flexibilities are particularly intended to promote access to affordable medication within developing States. Mandatory limitations and exceptions within an intellectual property regime can promote innovation, creativity and socially-beneficial uses. They are part of the "development agenda" promoted by the World Intellectual Property Organization among others and are reflected in international instruments including the Washington Declaration on Intellectual Property and the Public Interest. ${ }^{20}$ Such efforts counter the trend towards using international trade agreements to enact highly specific and enforceable proprietor rights.

As a global agreement on intellectual property standards, TRIPS is especially relevant for States lacking that level of protection. TRIPS primarily affects developing States by imposing minimum legal standards and requiring enforcement. TRIPS has had little effect in developed market economies which already have strong intellectual property rights protection. Thus Australia's adoption of TRIPS in 1995 did not necessitate significant change to its intellectual property laws (apart from lifting the standard patent term from 16 to 20 years). ${ }^{21}$

The Doha Declaration states that TRIPS "can and should be interpreted and implemented in a manner supportive of WTO members' right to protect public health and, in particular, to promote access to medicines for all." ${ }^{22}$ The U.S. Congress

18 Agreement on Trade-Related Aspects of Intellectual Property Rights (Apr., 15, 1994) Marrakesh Agreement Establishing the World Trade Organization, Annex 1C, Results of the Uruguay Round, 1869 U.N.T.S. 299, 33 I.L.M. 1143 (1994), [1995] ATS 38.

19 See e.g., Brook Baker, Arthritic Flexibilities for Accessing Medicines: Analysis of WTO Action Regarding Paragraph 6 of the Doha Declaration on the TRIPS Agreement and Public Health, 14 Ind. InT'L \& Comp. L. Rev. 613 (2003).

20 Global Congress on Intellectual Property and the Public Interest, Washington Declaration on Intellectual Property and the Public Interest, 3 (2011), available at http://infojustice.org/ wp-content/uploads/2011/09/Washington-Declaration-Print.pdf (last visited Jun. 7, 2016).

21 John Revesz, Trade-Related Aspects of Intellectual Property Rights (Australian Productivity Commission Staff Research Paper, May, 28, 1999).

22 World Trade Organization, Ministerial Declaration on the Trade-Related Aspects of Intellectual Property Rights (TRIPS) Agreement and Public Health of Nov. 14, 2001, WT/MIN(01)/DEC/2, 41 I.L.M. 755 (2002). 
committed itself to this Declaration and undertook to engage in "trade policies that promote access to affordable medicines." ${ }^{23}$ The U.S. Trade Representative was called upon to "honor" the Declaration's affirmation of a State's right "to use "to the full' the flexibilities" in TRIPS and "not place countries on the 'Special 301' Priority Watch List ... for exercising the flexibilities on public health provided for in the TRIPS Agreement." 24 The use of the "Special 301" program and bilateral free trade agreements to escalate intellectual property standards in developing States can undermine the intent of the Doha Declaration. ${ }^{25}$ Such techniques have generated opposition from international organizations and others, ${ }^{26}$ with one UN Special Rapporteur observing that:

$[\mathrm{N}]$ o rich State should encourage a developing country to accept intellectual property standards that do not take into account the safeguards and flexibilities included under the TRIPS Agreement. In other words, developed States should not encourage a developing country to accept 'TRIPS-plus' standards. ${ }^{27}$

The United States confronts mass copying of its intellectual property on a global scale. Its enforcement agenda springs from high intellectual property infringement in many States, particularly digital copyright "piracy." Forging links between international trade and intellectual property gives it additional leverage. Although its market size induced the acceptance of TRIPS by other States, TRIPS did not meet its strategic goals for greater international intellectual property rights protection. ${ }^{28}$ Presently dissatisfied with that regime, the United States (as well as the European Union) has used bilateral agreements as a strategy for "regime shifting." 29 It pursues an upwards "global ratchet" of intellectual property standards, which includes a "process of forum shifting ... from fora in which they are encountering difficulties" (such as the World Trade Organization and World Intellectual Property Organization) and "waves of bilaterals ... followed by occasional multilateral standard-setting." 30

The United States has moved through various international fora seeking to harmonise the world's intellectual property laws in its own image. The WTO was the primary forum during the 1980s and 1990s. But after TRIPS, other States became

\footnotetext{
S. Res. 241, 110th Cong. (2007).

H.R. Res. 525, 110th Cong. (2007).

25 Frederick Abbott, The Doha Declaration on the TRIPS Agreement and Public Health and the Contradictory Trend in Bilateral and Regional Free Trade Agreements (Quaker United Nations Office Occasional Paper 14, 2004).

26 Sean Flynn, Special 301 of the Trade Act of 1974 and Global Access to Medicine, 7 J. GENERIC Med. 309, 310 (2010).

27 U.N. Secretary-General, The Right of Everyone to the Enjoyment of the Highest Attainable Standard of Physical and Mental Health, Report of the Special Rapporteur, U.N. Doc A/61/338, 63 (Sept. 13, 2006).

28 Susan Sell, TRIPS Was Never Enough: Vertical Forum Shifting, FTAs, ACTA, and TPP, 18 Intell Prop. L. 447 (2011).

29 Laurence Helfer, Regime Shifting: The TRIPS Agreement and New Dynamics of International Intellectual Property Lawmaking, 29 YaLE J. InT'L L. 1, 6-9 (2004).

30 Peter Drahos, Expanding Intellectual Property's Empire: The Role of FTAs, International Centre for Trade \& Sustainable Development 7-9 (2003), available at http://ictsd.org/ downloads/2008/08/drahos-fta-2003-en.pdf (last visited Jun. 7, 2016).
} 
hostile to the U.S. agenda because, rather than a one-size-fits-all approach, ambiguity permitted governments to craft laws which best served their own policy objectives. The U.S. agenda then shifted to bilateral and plurilateral trade agreements. The Anti-Counterfeiting Trade Agreement, for example, was a plurilateral agreement which sought to establish a model that other States could accede to. The pursuit of greater intellectual property protection in successive bilateral and regional trade agreements has been partly driven by a U.S. desire to achieve standards it anticipated but failed to secure from TRIPS. The U.S. pharmaceutical industry also viewed TRIPS as falling short of its objectives, particularly preventing the delayed introduction of patent protection in those States which supply generic medicines.

Within several months of the Doha Declaration, the United States embarked on a bilateral and regional trade negotiation strategy incorporating "TRIPS-plus" intellectual property standards at odds with the intent of that Declaration. The United States offers increased market access to close allies and small economies in exchange for heightened commitments on domestic intellectual property regulation. This regulation greatly exceeded the minimum standards required by TRIPS and hindered resort to the flexibilities offered by it. ${ }^{31}$ National commitments typically extend the scope of patentability, limit patent revocation, extend patent terms, prohibit parallel importation, link patent status with regulatory approval, limit compulsory licensing, protect data protection and make obligatory accession to other multilateral intellectual property agreements. ${ }^{32}$ These TRIPS-plus conditions can impede States when addressing their own specific public health concerns. ${ }^{33}$ The agreements circumscribe the ways in which States might develop future programmes and limit the scope to respond to market failure, regulate drug prices or promote affordable access. ${ }^{34}$ The TRIPS-plus obligations pose potentially adverse impacts for each of these objectives. ${ }^{35}$

The United States bases its negotiation of free trade agreements on a model standard template. This template envisages a shared recognition of the importance of innovative pharmaceuticals in health care, research and development within the pharmaceutical industry and protecting intellectual property; promoting timely and affordable access to innovative pharmaceuticals through transparent, expeditious and accountable procedures; ${ }^{36}$ and recognizing the importance of innovative pharmaceuticals through procedures which value their objectively-demonstrated

$31 \quad$ Pedro Roffe \& Christoph Spennemann, The Impact of FTAs on Public Health and TRIPS Flexibilities, 1 Int'L. J. Intell. Prop. Mgmt. 75, 76-80, 86 (2006).

32 Cynthia Ho, A New World Order for Addressing Patent Rights and Public Health, 82 Chi.-Kent L. Rev. 1469, 1496 (2007).

33 See generally Beatrice Lindstrom, Scaling Back TRIPS-plus: An Analysis of Intellectual Property Provisions in Trade Agreement and Implications for Asia and the Pacific, 42 N.Y.U. J. InT'L L \& PoL. 917 (2010); Gaëlle Krikorian \& Dorota Szymkowiak, Intellectual Property Rights in the Making: The Evolution of Intellectual Property Provisions in US Free Trade Agreements and Access to Medicine, 10 J. World INT'L PROP. 388 (2007).

34 Susan Sell, TRIPS-Plus Free Trade Agreements and Access to Medicines, 28 LivERPOOL L.R. 41 (2007).

35 U.N. Development Programme, U.N. Aids, The Potential Impact of Free Trade Agreements on Public Health 3-5 (2012).

36 For example, AUSFTA annex 2C(1)(c) emphasises "timely and affordable access to innovative pharmaceuticals" through "transparent, expeditious, and accountable procedures." 
therapeutic significance. This template is then modified in light of contemporary negotiating conditions, past experience and the results of U.S. initiatives in other fora (including the World Health Assembly). The final text of a free trade agreement is the outcome of a unique negotiation process between the United States and the other party. Agreements can be tailored to the objectives of the parties and a State's relationship with the United States. No two bilateral agreements are identical.

Several substantive TRIPS-plus provisions commonly appear. These provisions relate to treaty accession, patent term extensions, data exclusivity, limiting compulsory licensing, protecting second-use patents, limits on excluding life forms from patentability, patent exhaustion, restricting parallel imports and various forms of patent linkage. ${ }^{37}$

The AUSFTA is one such TRIPS-plus arrangement. For example, Article 17.9.7 restricts compulsory licensing to a more stringent standard than under TRIPS. The United States, having failed in multilateral fora to restrict this exemption to specific diseases, has achieved a restriction to a TRIPS-plus standard of "national emergency, or other circumstances of extreme urgency." Article 17.9.8 of the AUSFTA locks the parties into enhanced protectionist patent terms (an extra five years maximum) if there are delays in issuing patent approval. Article 17.9.4 prohibits parallel importation, which is something the United States had not achieved through multilateral negotiations. According to the United States, parallel importation-including to address national public health emergencies-is inconsistent with Article 6 of TRIPS. ${ }^{38}$ However, the Doha Declaration leaves it to each WTO member to establish their own regime for exhausting intellectual property rights. Australia was repeatedly placed on the Special 301 watch list ${ }^{39}$ in the 1990 s because it loosened prohibitions on parallel imports in favour of significant economic benefits. Such a practice is largely unregulated under international copyright conventions and TRIPS leaves States parties free to allow parallel imports. A U.S. free trade agreement intends to modify that circumstance.

\section{Free Trade Agreements are Typically NeGotiated in SECRET}

In contrast to the open and transparent multilateral processes, the bilateral negotiating process for the AUSFTA was closed and secretive. ${ }^{40}$ This approach limits input and

37 Katrina Moberg, Private Industry's Impact on U.S. Trade Law and International Intellectual Property Law: A Study of Post-TRIPS US Bilateral Agreements and the Capture of the USTR, 96 J. Pat. \& TRAdemark OfF. Soc'y 228, 236, 244 (2014).

38 Frederick Abbott, The TRIPS-Legality of Measures Taken to Address Public Health Crises: Responding to USTR State-Industry Positions that Undermine the WTO, in The Political Economy of International Trade Law 320 (David Kennedy \& James Southwick eds., 2002).

39 The "Special 301" watch list enables the U.S. Trade Representative to designate those States which "deny adequate and effective protection" to intellectual property rights: Identification of Countries that Deny Adequate Protection, or Market Access, for Intellectual Property Rights Under Section 182 of the Trade Act of 1974 (Special 301), 63 Fed. Reg. 25539-01 (May 8, 1998).

40 Australia followed this approach for the China-Australia Free Trade Agreement, negotiations for which commenced in 2005 and concluded in 2014. The text was only publicly released in 2015 after signature. 
encourages informational asymmetry. Secrecy can be counter-productive because controversy is unnecessarily increased and the final text treated with derision. Such a strategy also risks backfiring if drafts are leaked. Intergovernmental negotiations for the AUSFTA were also characterised by a lack of public accountability. Stakeholder consultation occurred but without the agreement being available. Discussion, consultation and deliberation by the Australian government with stakeholders had hitherto occurred before important copyright amendments were made. Nevertheless, Australia asserted that it had consulted widely and that the AUSFTA's terms left flexibility in application.

A closed negotiation process has implications for interested non-governmental actors. Impeded access is not a concern for the U.S. pharmaceutical industry inasmuch as the U.S. Trade Representative is a captured regulatory agency. Industry unsurprisingly pursues high standards for intellectual property protection and enforcement, and linking these issues to productivity, economic growth, employment and living standards. Its research and development costs are partially funded by sales revenues. Pharmaceutical arbitrage-or the pricing gaps which encourage demand for cross-border pharmaceutical parallel trade-reduce the financial gains for States such as the United States which support product innovation. Voluntary differential pricing schemes which benefit low income consumers are also discouraged. But it is primarily a fear of arbitrage which justifies increased pharmaceutical intellectual property rights and related appropriation powers. Some forms of arbitrage are beneficial and deliver lower consumer prices without harming innovation. ${ }^{41}$ Indeed, the threat to innovation and public health comes not from arbitrage but counterfeit medications.

Australian special interest groups contributed to the AUSFTA negotiations with varying degrees of success. The higher education sector, for example, seized the opportunity to set a new agenda: the possibility of transforming the current closed set of fair dealing defences into a single broad exception derived from the U.S. fair use model. ${ }^{42}$ Such a possibility had been gestating since the 1990 s, notwithstanding uncertainty whether the U.S. model complied with international standards. ${ }^{43}$ Copyright infringement within a digital communications environment could be prevented, but the higher education sector would have to abandon its long-held reliance on a statutory licence framework. The public health sector, by contrast, has to become more engaged in future treaty negotiation processes than it was for AUSFTA to ensure that its particular interests are adequately represented and considered. ${ }^{44}$

41 Kevin Outterson, Pharmaceutical Arbitrage: Balancing Access and Innovation in International Prescription Drug Markets, 5 Yale J. Health Pol'y, L. \& Ethics 193 (2005).

42 Mary Wyburn, Higher Education and Fair Use: A Wider Copyright Defence in the Face of the Australia-United States Free Trade Agreement Changes, 17 A.I.P.J. 181, 203 (2006).

43 Ruth Okediji, Toward an International Fair Use Doctrine, 39 Colum. J. TRans'L. L. 75 (2000).

44 Peter Sainsbury, Australia-United States Free Trade Agreement and the Australian Pharmaceutical Benefits Scheme, 4 Yale J. Health Pol'y L \& Ethics 387, 399 (2004). 


\section{The Intellectual Property Provisions of a Free Trade Agreement can InFluenCE NATional HEALTH CARE SYSTEMS}

By concluding bilateral and regional agreements, the United States is gaining greater influence over the domestic health care and drug coverage programs of its trading partners. This trend has implications for access to and the affordability of pharmaceuticals. ${ }^{45}$ In particular, free trade agreements may not be an appropriate means of addressing issues of national health policy.

The U.S. (and Australian) pharmaceutical industry perceived a free trade agreement to present an opportunity to undermine the evidence-based, strict and effective procedures underpinning Australia's Pharmaceutical Benefits Scheme (PBS). ${ }^{46}$ The PBS is a longstanding universal pharmaceutical subsidy programme operated by the government which is widely praised as delivering high quality, efficient and fair health services. The purchasing power of the Australian government lowers drug costs, and subsidies ensure that Australians do not pay the true market price.

Unsurprisingly, the pharmaceutical industry criticises aspects of the PBS (particularly reference pricing and cost effectiveness) as a nontariff barrier to overseas markets and an abusive and discriminatory price control. The PBS limits the freedom of drug manufacturers to charge whatever the market will bear and does not allow them to recoup investment in research. Consumers are accessing innovative medicines without contributing substantively to their cost. Criticism about high medicine prices in the United States was deflected by claiming that Australia was "free-riding" on U.S. product development and undermining innovation.

A contrary position is that the PBS is not a trade barrier and free trade arguments are simply being enlisted to undermine social policies which are barriers to excess corporate profit. ${ }^{47}$ Although the PBS lowered pharmaceutical prices, it did not pose any tariff or quota barriers. The pharmaceutical industry wishes to derive rent from restrictive arrangements which exact higher prices. The changes to the PBS desired by U.S. manufacturers might transfer between AUD \$1.0 and \$2.4 billion per annum as profit. Industry's real concern was that the PBS effectively countered market power and remedied information asymmetry between customers and suppliers. Other countries, including some U.S. states, could implement a similar scheme, although the U.S. federal government was prevented from using its purchasing power to bargain down drug costs by industry-sponsored legislation.

For AUSFTA, U.S. negotiators pushed for enhanced transparency when evaluating drugs for inclusion in the PBS, an appeals mechanism for denied applications, and pricing mechanism changes. Australians were understandably concerned that AUSFTA would adversely affect their ability to obtain affordable

45 Carlos Maria Correa, Implications of Bilateral Free Trade Agreements on Access to Medicines, 84 Bull. World Health Org. 399 (2006).

46 See generally Deborah Gleeson, Kyla Tienhaara \& Thomas Faunce, Challenges to Australia's National Health Policy from Trade and Investment Agreements, 5 Med. J. Aus. 354 (2012).

47 Clive Hamilton, Buddhima Lokuge \& Richard Denniss, Barrier to Trade or Barrier to Profit? Why Australia's Pharmaceutical Benefits Scheme Worries U.S. Drug Companies, 4 Yale J. Health Pol’y., L. \& Ethics 373, 374, 377 (2004). 
medicine. The Australian government reassured the public that the PBS would not be dismantled and the AUSFTA would not lead to increased drug prices. After the treaty's conclusion, however, drug manufacturers expressed delight with the implications for prices, profits and investment. Whereas the PBS uses health economics and therapeutic referencing systems, AUSFTA promotes pharmaceutical reimbursement. Paragraph (d) of the Agreed Principles to AUSFTA suggests a compromise as follows:

The Parties are committed to facilitating high quality health care and continued improvements in public health for their nationals. In pursuing these objectives, the Parties are committed to the following principles:

(a) the important role played by innovative pharmaceutical products in delivering high quality health care;

(b) the importance of research and development in the pharmaceutical industry and of appropriate government support, including through intellectual property protection and other policies;

(c) the need to promote timely and affordable access to innovative pharmaceuticals through transparent, expeditious and accountable procedures, without impeding a Party's ability to apply appropriate standards of quality, safety and efficacy; and

(d) the need to recognize the value of innovative pharmaceuticals through the operation of competitive markets or by adopting or maintaining procedures that appropriately value the objectively demonstrated therapeutic significance of a pharmaceutical.

Most provisions affecting the PBS are located in Annex 2-C (Pharmaceuticals), Chapter 17 (intellectual property rights) and side-letters between Australian Trade Minister Vaile and U.S. Ambassador Zoellick confirming certain understandings. The United States and Australia both espoused victorious but somewhat contradictory messages, possibly to sooth domestic constituencies. The U.S. Trade Representative indicated that "Australia will make a number of improvements in its Pharmaceuticals Benefits Scheme (PBS) procedures that will enhance transparency and accountability in the operation of the PBS, including establishment of an independent process to review determinations of product listings." 48 The Australian Department of Foreign Affairs and Trade, by contrast, stated that "[t]he Pharmaceutical Benefits Scheme (PBS), in particular the price and listing arrangements that ensure Australians access to quality, affordable medicines, remains intact." ${ }^{49}$

In Australia considerable attention focused on AUSFTA's impact on the PBS. ${ }^{50}$ The agreement did not eliminate the PBS or make any substantive changes. Thus

48 United States Trade Representative, Summary of the US-Australia Free Trade Agreement, Free Trade "Down Under" (Feb. 8, 2004).

49 Austrade, Free Trade Agreement with the United States (Feb. 9, 2004).

50 Austl. Dep't of Health \& Ageing, Australia-United States Free Trade Agreement and the Pharmaceutical Benefits Scheme, 2005; Kate Burton \& Jacob Varghese, The PBS and the Australia-U.S. Free Trade Agreement, Australian Parliamentary Library Research Note No. 3 (2004); Maurice Rickard, Free Trade Negotiations, the PBS and Pharmaceutical Prices, Parliament of Australia (Feb. 10, 2004); Ken Harvey, Thomas Faunce, Buddhima Lokuge \& Peter Drahos, Will the Australia-United States Free Trade Agreement Undermine the Pharmaceutical Benefits Scheme?, 181 Med. J. Aust. 256 (2004). 
a U.S. free trade agreement might not significantly affect drug prices or jeopardise access to affordable medicine. Interestingly Canada, like Australia, wished to protect its citizens from high drug prices and faced pressure from the U.S. drug industry. ${ }^{51}$ The substantive legal changes effected to the Canadian system under the North American Free Trade Agreement ${ }^{52}$ were relatively more extensive than under the AUSFTA. However, Canada can still provide access to affordable pharmaceuticals. The AUSFTA left Australia's subsidisation programme substantively intact and effected only minor procedural change to PBS' operation. Communication was improved through enhanced decision-making transparency, a non-binding independent review process, consultative opportunities with applicant pharmaceutical companies and bilateral dialogue through a Medicines Working Group. Generic drug applicants in Australia must now meet certification requirements which are similar to Canada's "notice of compliance" conditions. Australia also indicated that many AUSFTA provisions required practices which were already followed when new medications were considered for listing. ${ }^{53}$ Again, however, this assessment may have been issued to temporarily appease local constituencies.

Overall, the AUSFTA did not create any immediate and measurable price rises. Indeed, certain outcomes benefited the PBS. Greater listing transparency and enhanced stakeholder engagement brings openness and certainty to the process. ${ }^{54}$ One long-term concern is that such measures shift the balance of power from Australia to the pharmaceutical industry. Some U.S. expectations will become disappointed if there is no concrete change (even if the United States may have to defend several of its own subsidised drug programmes). The final text expressed neither the absolute wishes of the U.S. nor Australia, and a compromise agreement which appears to benefit both States was produced.

That said, AUSFTA transformed intellectual property protection into a foreign policy issue. The Department of Foreign Affairs and Trade (responsible for conducting negotiations) focused on the treaty text and overlooked copyright policy goals. And whereas Australia could previously formulate its own policy position, it now has to be satisfied that Australian law and practice complies or is consistent with its AUSFTA obligations. ${ }^{55}$ Australian intellectual property law is henceforth "extensively governed" by multilateral and bilateral treaty commitments. ${ }^{56}$

51 Katherine Van Marent, Bartering with a Nation's Health or Improving Access to Pharmaceuticals? The United States-Australia Free Trade Agreement, 14 PAC. RIM L. \& Pol'y J. 801, 816, 820 (2005). See also James Silbermann, The North American Free Trade Agreement's Effect on Pharmaceutical Patents: A Bitter Pill to Swallow or a Therapeutic Solution?, 12 J. Contemp. Health L. and PoL'y. 607 (1996).

52 North American Free Trade Agreement (NAFTA), U.S.-Canada-Mexico (Dec. 17, 1992) 32 I.L.M. 289 (1993).

53 Department of Foreign Affairs \& Trade, The Australia-United States Free Trade Agreement: Pharmaceutical Benefits Scheme (PBS) Outcomes, Backgrounder (2004).

54 Bryan Mercurio, The Impact of the Australia-United States Free Trade Agreement on the Provision of Health Services in Australia, 26 WhitTIER L. Rev. 1051, $1097-9$ (20042005).

55 Commonwealth Parliamentary Debates, House of Representatives Hansard, 22, 31 (Dec. $5,2005)$.

56 Austl. Gov't, Government Response to the Final Report of the Senate Select Committee on the Free Trade Agreement between Australia and the United States of AMERICA, 4 (2004). 


\section{E. The Impacts of a U.S. Free Trade Agreement May Not Be Clear}

The impacts of a U.S. free trade agreement are not self-evident.$^{57}$ On one hand is the view that such an agreement offers marginal effects. Many AUSFTA intellectual property provisions clarify or reconfirm existing law. For example, the information dissemination requirements for pharmaceutical manufacturers are not novel but merely reiterate the legal position then prevailing in the United States and Australia. Australia also stated during negotiations that many of the intellectual property provisions were already reflected under Australian law, policy or practice. Australia already complied with certain AUSFTA articles or needed to implement only minor legislative change. Some provisions (such as extending copyright terms from 50 to 70 years) brought Australia into line with the United States and the European Union (EU).

The United States claimed to have made substantive gains in intellectual property rights protection through AUSFTA but the outcome fell short of its ambitions. ${ }^{58}$ The AUSFTA expanded the scope of patentability, limited patent revocation and compulsory licensing, prohibited parallel imports, extended test data protection, and imposed patent linkage and patent term extension provisions. But Australia already conformed to high (including some TRIPS-plus) standards prior to the AUSFTA, and several provisions (including patent term extension, data protection and prohibiting parallel imports) were reflected under Australian law. Nevertheless, these standards have been "future-proofed" by the AUSFTA (that is, prevent future domestic policy flexibility to reduce or remove them). Others provisions which appear to introduce substantive change have either been effectively nullified within the text itself or, while limiting Australia's future options, have had no material impact to date. ${ }^{59}$

Some provisions which initially aroused controversy offer little if any real change for Australia. For example, Article 17.10.4 of the AUSFTA requires Australia to implement measures which prevent pharmaceutical product marketing that is alleged to be patent-infringing. In other words, pharmaceutical marketing approval is linked with patent validity. Concerns were expressed that this would encourage patent "evergreening": that is, effectively extending existing patents beyond their 20 year term by obtaining additional patents on different aspects of the same product. The practice is a regulatory barrier for market entry by generic manufacturers and endemic in the United States and Canada. In 2004 amendments were made to the Therapeutic Goods Act 1989 (Cth) to establish a certification process. ${ }^{60}$ But despite the political rhetoric, media debate and academic speculation, these amendments

57 Compare, for example, Thomas Faunce et al, Assessing the Impact of the Australia-United States Free Trade Agreement on Australian and Global Medicines Policy, 1 GLoB'N. \& Health 1 (2005); Lauren McLeod, Andrew McRobert \& David Wilson, Australia-U.S. Free Trade Agreement-Impact on Intellectual Property Rights, 16 I.P.L.B. 153 (2004).

58 Peter Drahos, Buddhima Lokuge, Tom Faunce, Martyn Goddard \& David Henry, Pharmaceuticals, Intellectual Property and Free Trade: The Case of the U.S.-Australia Free Trade Agreement, 22 Prometheus 243, 249 (2004).

59 Kevin Outterson, Agony in the Antipodes: The Generic Drug Provisions of the AustraliaU.S.A. Free Trade Agreement, 2 J. GEN. Med. 316, 321 (2005).

60 Canada implemented a similar scheme in 1993 after entering the North American Free Trade Agreement. 
do not increase the prospect of evergreening because the ability to do so already existed under Australian law. ${ }^{61}$ Indeed, additional "anti-evergreening" amendments allow Australia's Attorney-General to join injunctive applications by brand name patent holders against generic manufacturers and claim damages if a price rise occurs under the PBS. ${ }^{62}$

An alternative position is that the AUSFTA effected considerable change albeit not yet apparent. The AUSFTA demonstrated that free trade agreements can reach farther into domestic policy than ever imagined before. ${ }^{63}$ Although not requiring change from either signatory, the AUSFTA locked-in existing law so that future governments cannot modify or repeal it without breaching or re-negotiating the treaty.

On this view, the AUSFTA contained detailed obligations and a strict implementation timetable which drove rapid, wholesale amendment of Australian copyright law. However, there was a pre-existing domestic reform agenda which the agreement partly galvanised and partly blocked, as well as setting a wholly new policy agenda post-AUSFTA. ${ }^{64}$ Before 2004 various Australian copyright laws had been reviewed by law reform and other bodies. Many recommendations were unaddressed for a long time, thereby suggesting that they were difficult to implement if not unworkable. AUSFTA negotiations rendered moot many proposals because Australia's digital copyright law would have to be rewritten to fit the U.S. model. Significant change across the copyright regime would have to be made to implement the treaty as planned, some of which was contrary to previous assessments of national interest. AUSFTA made some already pending copyright changes more urgent, changed the policy environment and pushed aside much of the domestic law reform agenda. Controversy was further intensified by a short consultation period and a bare understanding of some provisions. Mistakes were made. Copyright reform dominated the political agenda and became a publicly salient issue (not least because of mass infringement by the Australian public). The government opted to pass a single, omnibus copyright-amending Act. 2004 was a "stormy" time for Australian copyright law because changes required by the AUSFTA interacted with several formally unrelated legislative reviews. ${ }^{65}$

In the post-AUSFTA environment, some copyright reviews were prompted by the treaty whereas others were not. For example, a new safe harbour regime was introduced for internet service providers because of the AUSFTA. ${ }^{66}$ But several

${ }_{61}$ Rhonda Chesmond, Patent Evergreening in Australia After the Australia-United States Free Trade Agreement: Floodgates or Fallacy, 9 FlindERS J. L. REF. 51, 61 (2006).

62 In response, the U.S. Trade Representative reserved the rights of the U.S. in a final exchange of letters. The Australian Minister for Trade acknowledged that a difference of opinion had arisen which was insufficiently significant to prevent the AUSFTA from proceeding.

63 Laura Chung, AUSFTA, KORUS FTA and Now TPP: Free Trade AgreementsAre Now Reaching Further into Domestic Health Policies than Ever Before, 22 CuRRENTS: InT'L TRADE L.J. 26, 27 (2013).

${ }^{64}$ Kimberlee Weatherall, Of Copyright Bureaucracies and Incoherence: Stepping Back from Australia's Recent Copyright Reforms, 31 Melb. U. L. Rev. 967 (2007).

65 Id. at 985.

66 See generally YiJun Tian, WIPO Treaties, Free Trade Agreement and Implications for ISP Safe Harbour Provisions (The Role of ISP in Australian Copyright Law), 16 BOND L.R. 186 (2004). 
amendments were not similarly required but were instead domestic responses to the perceived strengthening of copyright law occasioned by the agreement. A perceived need to comply with prescriptive AUSFTA provisions prompted public processes which took into account Australian interests and skirted wholesale adoption of controversial U.S. aspects. Although some features of U.S. copyright law were clearly adopted, there was simultaneously a deliberate process of distancing Australia from U.S. approaches. ${ }^{67}$

In sum, Australia strove to do the absolute minimum necessary to implement its treaty obligations. For example, AUSFTA gave Australia only limited options on how to enact new anti-circumvention laws. Although the agreement summarised the U.S. system for managing copyright exceptions, reference to the associated U.S. machinery was omitted from the text and Australia was left with some choice as to how to manage the system and by whom. Ultimately the final arrangement looks very little like the U.S. model which formed the basis for the AUSFTA provision. ${ }^{68}$

Australians were assured that the PBS would not be adversely affected by the AUSFTA. Academics, non-government organizations and others were worried that the U.S. had obtained substantial inroads. The Agreed Principles of Annex 2C, for example, supported the valuation of "innovative pharmaceuticals." Procedural changes included establishing an independent review process and providing hearing opportunities for applicants before an expert formulary committee, the Pharmaceutical Benefits Advisory Committee (PBAC). Such changes, it was feared, would facilitate greater industry influence in decision-making, undermine the PBAC's capacity to deliver independent, evidence-based assessments, and erode Australia's capacity to ensure value for money. A joint U.S.-Australian discussion forum, the Medicines Working Group, was the means by which the United States would direct or influence future domestic policy-making in Australia around medicines.

Admittedly, the gains made by the United States were limited to matters of process and transparency in the formulary listing process. But there is no evidence that the AUSFTA impacted upon PBS decision-making, pricing mechanisms, or actual medicine prices. Many of AUSFTA's substantive provisions either reflected existing practices about transparency and timeliness, or were improvements to PBAC processes already underway or proposed. The independent review process cannot remake PBAC decisions and is only a quality assurance mechanism. The Medicines Working Group is a discussion forum having limited terms of reference, is chaired by health officials, and has no decision-making, advisory or reporting function.

By way of further illustration, the AUSFTA ostensibly permits direct to consumer advertising (DTCA) via the internet. ${ }^{69}$ However, this is subject to

67 See Evidence to Senate Select Committee on the Free Trade Agreement between Australia and the United States of America, Parliament of Australia, Canberra, 67 (Dep't Foreign Affairs \& Trade, Stephen Deady) (Jun. 3, 2004); Evidence to House of Representatives Standing Committee on Legal and Constitutional Affairs, Parliament of Australia, Canberra, 29 (Helen Daniels) (Dec. 5, 2005).

68 Emma Caine \& Kimberlee Weatherall, Australia-U.S. Free Trade Agreement: Circumventing the Rationale for Anti-Circumvention?, 7 INTERNET L. Bull. 121 (2005).

69 AUSFTA, annex 2-C, art. 5 ("Each Party shall permit a pharmaceutical manufacturer to disseminate ... through the manufacturer's Internet site ... truthful and not misleading 
dissemination under a Party's laws, regulations and procedures. DTCA continues to be prohibited in Australia. The rationale for retaining a provision within a negotiating template, even if a carve-out has been agreed, is to achieve a perception on the part of interested Sates that a normative provision was accepted which can be legitimately included in future trade agreements. Australia gained by including a specific treaty obligation about public transparency which facilitates disclosure of PBAC processes, evidence and outcomes to a degree which the pharmaceutical industry had previously resisted.

Perhaps most importantly, the prices of PBS medicines have not risen since the AUSFTA. Indeed, under administrative arrangements introduced in 2005 to reduce the price of generic products, the prices of many still-patented PBS medicines have been reduced. In 2007, when the PBS was separated into two formularies, it was feared that Australia had caved to U.S. pressure through the Medicines Working Group to dismantle reference pricing. However, the changes were a domestic response to longstanding concern about the need to reduce the price of generic products, take advantage of many patent expiries and generate savings to offset new listing costs.

It is disconcerting then that U.S.-Australia negotiations occurred despite a paucity of data. ${ }^{70}$ Uncertain future impacts can be addressed through econometric studies of the likely impact of U.S. free trade agreements. For example, Oxfam estimated that between 2001 and 2006, the Jordan-U.S. Free Trade Agreement caused a 20 percent overall increase in medicine prices, and that data protection provisions delayed the introduction of generic equivalents for 79 percent of new medicines. ${ }^{71}$ The putative benefits of this treaty promoted at the time of its conclusion were not realised: there was no increased foreign direct investment in Jordan's pharmaceutical industry, greater research and development or swifter introduction of innovative medicines.

\section{F. A U.S. Free Trade AgreEment Does Not NeCESSARILy LEad to A Harmonization of or ConVERGENCE BETWEen NATional LEGAL SyStems}

The U.S. pharmaceutical industry has long objected to the lack of harmonization, particularly about marketing approval requirements imposed by national regulatory authorities. Governments also wish to induce companies to bring new medicines to market more quickly. Thus simplified registration standards and processes might speed up market entry, especially if differential requirements deter innovators.

The trajectory of national intellectual property laws has been influenced by TRIPS. Whether TRIPS was beneficial for Australia cannot be assessed in isolation but requires considering all of Australia's gains and losses under the WTO

information regarding its pharmaceuticals that are approved for sale in the Party's territory").

70 Australia largely relied on Centre for International Economics, Economic Analysis of

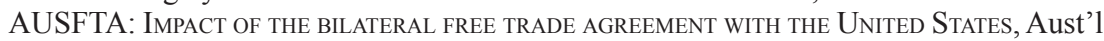
Dep't Foreign Affairs \& Trade (2004).

71 Oxfam International, All Costs, No Benefits: How TRIPS-Plus Intellectual Property Rules in the U.S.-Jordan FTA Affect Access to Medicines, Oxfam Briefing Paper, 2, 15 (2007). 
agreements then under negotiation. TRIPS was not thought to be in Australia's national interest because Australia is a net importer of intellectual property. But Australia's intellectual property exports are now growing faster than its imports. ${ }^{72}$ Furthermore, TRIPS was one factor which drove the convergence of Australian and U.S. patent law. However, more subtle forces are also at play. For example, Australia has also adopted U.S. practices with respect to antitrust law, contract law, securities law, bankruptcy law and corporate law. ${ }^{73}$ Explanatory variables include a common language, significant reciprocal trade, common trading partners, convenient trans-Pacific travel and exchanging popular culture.

Commentators disagree on whether the AUSFTA contributed to a harmonisation of intellectual property standards between U.S. and Australian law. ${ }^{74}$ Some significant convergence of patent law was directly attributable to TRIPS. ${ }^{75}$ Australia's regime for technological protection is now largely modelled on the U.S. framework following AUSFTA's implementation. ${ }^{76}$ However, the bulk of the changes preceded that agreement because Australian law naturally developed along U.S. lines in order to address common challenges. Australian intellectual property law ordinarily requires reflecting on U.S. legal developments given the size and importance of the U.S. market. In 2001 there were still differences between U.S. and Australian patent law. Indeed, several instances of divergence in Australia may have been encouraged by dissatisfaction with TRIPS. Australia currently provides a much higher level of protection for industrial designs than the U.S. The AUSFTA merely requires each Party to "endeavour to reduce differences in law and practice" between industrial design systems (Article 17.8.2, AUSFTA). Thus change is not required for an issue in which harmonisation would have increased protection in the U.S. Designs law between the United States and Australia is not identical, and there is no reciprocity of protection. This divergence is also explicable by reason of Australia's particular trade policy and competition laws.

\section{G. A FreE TRADE AgreEment CAN INFLUENCE Future INTERNATIONAL ARRANGEMENTS}

Successive free trade agreements build on their predecessors. The United States has established a web of free trade agreements with Canada and Mexico (1992), Jordan (2001), Singapore (2003), Chile (2003), several Central America States (2004), Bahrain (2004), Morocco (2004), Peru (2006), Oman (2006), Panama (2007) and

72 In 2002, before the conclusion of the AUSFTA, the U.S. received around $\$ 834 \mathrm{~m}$ in intellectual property royalties from Australia as compared with $\$ 723 \mathrm{~m}$ from China.

73 Paul von Nessen, The Americanization of Australian Corporate Law, 26 Syracuse J. INT'L L. \& CoMm. 239, 242, 245, 264-5 (1999).

74 For an overview of the legislative changes which were required to Australian patent law to accord with AUSFTA, see Lauren McLeod, Andrew McRobert \& David Wilson, Australia-U.S. Free Trade Agreement-Impact on Intellectual Property Rights, 16(10) I.P.L.B. 153 (2004).

75 Joshua Harrison, On the Convergence of U.S. and Australian Patent Law, 2 Melв J. INT'L L. 351, 372 (2001).

76 Gwen Hinze, Brave New World, Ten Years Later: Reviewing the Impact of Policy Choices in the Implementation of the WIPO Internet Treaties' Technological Protection Measure Provisions, 57 CASE W. Res. L. Rev. 779 (2007). 
South Korea (2007). For example, much of the AUSFTA intellectual property chapter was imported from agreements concluded by the U.S. with Chile and Singapore. ${ }^{77}$ The AUSFTA was the U.S.' first attempt to test whether a bilateral trade agreement could bind another State on domestic public health policy. The Korea-U.S. Free Trade Agreement (KORUS) was a second attempt. Both the AUSFTA and KORUS contain provisions by which the U.S. tried to limit the autonomy of its trading partners in evaluating, selecting, valuing and reimbursing medicines listed on their national formularies. For Australia, the U.S.' attempt was largely unsuccessful. ${ }^{78}$ Nevertheless, the AUSFTA established an unfortunate precedent because it was the basis upon which the United States built for its approach to Korea. The U.S. was determined to succeed for KORUS where its efforts had been frustrated for AUSFTA by enhancing the market's role in determining the demand and prices of reimbursed medicines. It becomes increasingly difficult for third States to resist U.S. pressures and introduce generic medicines when other States have concluded a bilateral arrangement. Fences are being built around increasingly-isolated States such as India and Brazil which manufacture generic products.

More recent patent law proposals go further than both AUSFTA and KORUS. The Trans-Pacific Partnership (TPP) between twelve States including the United States and Australia poses the most aggressive intellectual property provisions for pharmaceuticals to date. ${ }^{79}$ The intellectual property chapter heightens protection standards for rights holders beyond which the evidence supports, insufficiently ensures the interests of users, consumers or the public and is particularly harmful for developing States. ${ }^{80}$ The text is also a bad bargain for participating States from a public health perspective.$^{81}$ The plant patent provisions could also seriously disrupt traditional farming practices within the Pacific Rim and threaten food security in poor farming communities.

For three reasons, the dynamics of the TPP do not favor the maximalist position proposed by the United States. First, the United States seeks to convince relatively poor States to adopt the same or higher intellectual property protection and enforcement mandates that exist in the U.S. or are reflected in agreements

77 On the free trade agreement with Singapore, see Peter Kang \& Clark Stone, IP, Trade, and U.S./Singapore Relations-Significant Intellectual Property Provisions of the 2003 U.S.-Singapore Free Trade Agreement, 6 J. WorLd InT'L. Prop. 721 (2003); Kenneth Chiu, Harmonizing Intellectual Property Law between the United States and Singapore: The United States-Singapore Free Trade Agreement's Impact on Singapore's Intellectual Property Law, 18 TRANSNAT'L L. 489, 509 (2005).

78 Ruth Lopert \& Deborah Gleeson, The High Price of "Free" Trade: U.S. Trade Agreements and Access to Medicines, 41 J.L. Med. \& Ethics 199, 205 (2013).

79 For background, see Roma Patel, A Public Health Imperative: The Need for Meaningful Change in the Trans-Pacific Partnership's Intellectual Property Chapter, 16 MinN. J.L. SCI. \& TeCh. 477 (2015). For Australia's position, see Department of Foreign Affairs and Trade, Trans-Pacific Partnership Agreement Negotiations (2016), available at http://www.dfat.gov.au/fta/tpp (on file with the author).

80 Sean Flynn, Brook Baker, Margot Kaminski \& Jimmy Koo, The U.S. Proposal for an Intellectual Property Chapter in the Trans-Pacific Partnership Agreement, 28 Ам. U. InT'L L. Rev. 105, 119 (2012).

81 Burcu Kilic, Hannah Brennan \& Peter Maybarduk, What is Patentable Under the TransPacific Partnership? An Analysis of the Free Trade Agreements Patentability Provisions from a Public Health Perspective, 40 Yale J. Int'L L OnLine 1 (2015). 
concluded with high-income countries. The United States wishes to selectively export the protections available under U.S. law but not the exceptions. States which accepted these standards in free trade agreements sought to achieve access to U.S. markets, and many TPP States have already implemented these agreements. U.S. proposals moreover abandon data-exclusivity flexibilities which were granted to Peru and Colombia in free trade agreements concluded with them.

Second, the United States intends to harmonize substantive patent and data protection law in TPP member States to U.S. standards. The proposals build upon recent free trade agreements by restraining the flexibility permitted under TRIPS. This position adversely affects the availability of affordable medicines in developing States and increases the price of inputs for many industries. The TPP prevents pharmaceutical innovators in developing countries from undertaking research and development via reverse engineering and creating functional equivalents or product improvements. The TPP will prevent independent action by States to develop generic medicines. Prospective parties would be unable to adopt the kind of pregrant opposition processes found to be useful in India. U.S. proposals are a longterm campaign to implement standards that will ultimately be globalized to include India among others.

Third, the TPP contains provisions which have previously been considered and rejected by States during the TRIPS negotiations. One provision in TRIPS, for example, permitted the U.S. to continue to implement its own relatively lax standard on patentability without requiring other States to do so. The TPP, however, potentially exports that standard to all member States. Patent/registration linkage is not mentioned in TRIPS or required in many States, including most TPP countries. Nevertheless, it has become a common feature of U.S. free trade agreements.

\section{H. A Free Trade Agreement Must Reconcile Competing Cultures and PeRSPECTIVES}

Is the U.S. model an appropriate global standard? Standards which increase intellectual property protection but constrain domestic drug coverage programmes advance pharmaceutical industry interests and attempt to export and impose U.S. values abroad. Free trade agreements reflect the U.S.' enduring adherence to market-based solutions, coupled with a conviction that government intervention is unnecessary and unhelpful. Thus the U.S. Trade Representative is mandated to pursue "the elimination of government measures such as price controls and reference pricing which deny full market access for United States products" in overseas markets. ${ }^{82}$ This is despite the U.S. health care system itself exhibiting the characteristics of market failure.

One U.S. objective regarding trade-related intellectual property rights is that the "provisions of any multilateral or bilateral trade agreement ... entered into by the United States reflect a standard of protection similar to that found in United States

82 Trade Promotion Authority Act, Public Law No. 107-210 (2002); InTERnational Trade Administration, Pharmaceutical Price Controls in OECD Countries: Implications for U.S. Consumers, Pricing, Research and Development, and Innovation, U.S. Department of Commerce (2004). 
law." ${ }^{83}$ U.S. proposals do not purely reflect U.S. law (particularly legal principles or judicial interpretations) and run counter to the national law of proposed parties. Nor do they reflect the tempering standards or qualifications available under U.S. law. Although essentially based on the principles of U.S. intellectual property law, free trade agreements omit important checks and balances that mitigate their effects in the United States. Furthermore, some provisions could be a back-door means of compelling recognition of an issue. For example, enabling triple damages for patent violations is extreme because U.S. law confines such awards to wilful patent infringement. The TPP standard does not contain this precondition which might not be appropriate for all States. Another TPP proposal requires that nearly every copyright violation is a criminal offence, thereby implementing a position which the United States lost in a recent WTO dispute with China ${ }^{84}$

The United States deploys an aggressive trade agenda to expand markets for U.S. goods and services which can clash with the social equity or fairness objectives of other States. ${ }^{85}$ The United States promotes a distinctive vision on the governmental role to advance markets but also a desire to safeguard its national industry. The U.S. bilateral trade agenda not only undermines the pursuit of valuedriven health care by its trading partners but remakes other nations' health systems in its own image. Those interests that promote notions of choice or freedom and resist government pricing structures in the United States also consider eliminating comparable constraints in the global economy to be equally essential.

Current U.S. strategy is damaging its own political interests because the United States will not secure substantive copyright harmonisation or build longterm support for future multilateralisation of its preferred standards. An apparent disregard for Australian traditions generated a perception of U.S. unilateralism, double standards and high-handed ignorance. ${ }^{86}$ Australia's reaction was sustained, hostile and sprung from many sources. ${ }^{87}$ The United States was perceived to have imposed its copyright rules on Australia, watched implementation with a critical eye and demonstrated scant regard for Australian sovereignty or its Parliamentary processes. The AUSFTA was overly-detailed, its "standard form" failed to respect Australian traditions and suggested that the United States had a petty and patronizing attitude. Australians resented being scolded by a country that had long failed to adequately protect foreign authors and itself refused to wholly conform to international norms.$^{88}$ AUSFTA sought to lock Australia into a U.S. domestic legal position whose appropriateness was too early to determine. Although the United States is theoretically vulnerable insofar as treaty obligations apply reciprocally, AUSFTA could be ignored where it proved inconvenient to the U.S.

83 Trade Act of 2002 \$2102(b)(4)(a)(i)(II), 19 U.S.C. $\$ 3802(\mathrm{~b})(4)(\mathrm{A})(\mathrm{i})(\mathrm{II})$ (2006) (emphasis added).

84 See further Daniel Gervais, China-Measures Affecting the Protection and Enforcement of Intellectual Property Rights, 103 Aм. J. InT'L L. 549, 552-53 (2009).

85 Ruth Lopert \& Sara Rosenbaum, What is Fair? Choice, Fairness and Transparency in Access to Prescription Medicines in the United States and Australia, 35 J.L. Med. \& Eтнісs 643, 651 (2007).

86 Robert Burrell \& Kimberlee Weatherall, Exporting Controversy? Reactions to the Copyright Provisions of the U.S.-Australia Free Trade Agreement: Lessons for U.S. Trade Policy, U. ILl. J.L. TeCh. \& Pol'y 259 (2008).

87 Id. at 283-5.

88 Id. at $288,291$. 
Furthermore, the gains produced by the AUSFTA were at best limited. ${ }^{89}$ AUSFTA did very little to bring the U.S. and Australian copyright systems closer together and any harmonisation is little more than superficial..$^{90}$ The AUSFTA did not compel Australia to lift copyright standards, and its implementation under Australian law produced outcomes which diverge from the U.S. position. Thus significant conceptual and structural differences remain between U.S. and Australian copyright law. Rather surprisingly for a bilateral agreement, the AUSFTA did not address the individual circumstances of the contracting parties. ${ }^{91}$ Nor did AUSFTA secure a meaningful increase in protection standards for U.S. copyright holders. Indeed, the increases resulting from AUSFTA are not all favourable to those interests and are unlikely to be welcome.

A free trade agreement with the United States must accommodate a nation's historical trajectory, competing ideology and different philosophy. ${ }^{92}$ Whereas the United States emphasizes innovation as the fundamental tenet, Australian public health care policy has historically focused on equity and distributive justice. Contemporary pharmaceutical policy developments taking place at the time when negotiations with the United States are occurring will also be influential. There are also global trends which run counter to bilateral agreements, including stronger national regimes and technological solutions. Ultimately a State contemplating a U.S. agreement must balance the interests of rights holders with those of users and the community.

Trade partners require space to implement their international obligations in a manner that satisfies their particular circumstances. One of the pitfalls of bilateralin contrast to multilateral-negotiations is exposure to bargaining power inequality. Powerful States can demand much and offer little in terms of market access. For example, a U.S. free trade agreement from Malaysia's point of view is likely to adversely affect pharmaceutical product access because the intellectual property protections exceed what is appropriate for its social and economic needs..$^{93}$ Access to affordable medicine can be delayed or put beyond the reach of Malaysians, and the drive towards innovation might not be appropriately balanced against public health.

Consensus from the European Union is vital if a new multilateral standard is to be established. But the European Union may not accept the U.S.' lead in setting new international intellectual property standards. Europe has distinctive philosophical underpinnings to copyright protection. For example, all economic rights in copyright must be "freely and separately" transferable, and persons acquiring copyright by contract shall "enjoy fully the benefits derived from that right" (Article 17.4.6(a), AUSFTA). Other recent U.S. free trade agreements contain similar provisions. The United States evidently seeks to prevent trade partners from introducing unwaivable or unassignable rights of a kind that enjoys support within Europe.

\footnotetext{
Id. at 261 .

Id. at 270,306 .

Id. at 298, 301-2.

Patricia Ranald, The Australia-U.S. Free Trade Agreement: A Contest of Interests, 57 J. Austl. Pol. Econ. 30 (2007).

93 Robert Galantucci, Data Protection in a U.S.-Malaysia Free Trade Agreement: New Barriers to Market Access for Generic Drug Manufacturers, 17 Fordham Intell. Prop. Media \& Ent. L.J. 1083, 1099 (2007).
} 
Germany and Austria, for example, prohibit the outright assignment of copyright. Article 17.4.6(a) could also prevent unwaivable rights to equitable remuneration (such as those created under the EU's Rental Rights Directive) and exclude the compulsory collective administration of rights (which enjoys some popularity in Europe). One provision in AUSFTA about the graphic representation of trademarks intends to ensure that Australia does not follow the European approach which has made it almost impossible to register olfactory marks. In sum, there are formidable political and cultural obstacles deterring the European Union from subscribing to the standards laid down in recent U.S. free trade agreements.

\section{Conclusions}

The trend towards bilateral agreements reflects U.S. dissatisfaction with decisionmaking in multilateral fora. Although the United States sought to lock Australia into a TRIPS-plus position-and one which does not purely reflect the entirety of U.S. law-AUSFTA was also negotiated with an eye to non-party third States. In Australia's case, bilateral negotiations highlighted a conflict between commercial ambitions (including innovation and efficiency) with public health goals (namely, prices based on therapeutic value which promote affordable access). Considered overall, U.S. efforts to remake Australia's health care system in its own image proved largely unsuccessful. Thus rhetoric must be distinguished from reality when other States are contemplating the value and likely impact of concluding a U.S. free trade agreement. 